\title{
FORMATION OF SPIRITUAL AND MORAL VALUES IN MODERN CHECHEN REPUBLIC
}

\author{
C) Ramzan Kh. Daudov \\ Chechen state university. Grozny, Russian Federation \\ sapsan189@mail.ru
}

In modern Chechen Republic a special concept is formulated. It includes the spiritual and moral education of the younger generation. This concept promotes the development of such fundamental values as patriotism, religiosity and traditionalism. Having gone through many trials and difficulties throughout history, the Chechen people have come to a peaceful and prosperous way of life. Of course, this is largely due to the successful policies of such statesmen as the President of the Russian Federation V.V. Putin and AkhmadHadzhi Kadyrov, whose way to this day is being continued by his son, the head of the Chechen Republic, Ramzan Akhmatovich Kadyrov. To form true values in the republic, all representatives of the government, the clergy and the people themselves are involved. The presence in the world of such trends as Islamic modernism and traditionalism also influenced the formation of the spiritual and moral values of Chechen society. From many sources it is known that representatives of traditionalism advocate the preservation of those values that were still in the time of the Prophet Muhammad (the beginning of the VII century). Otherwise, representatives of modernism believe that it is necessary to adapt traditional values in the modern world. Modern Chechen Republic copes brilliantly with the problem of opposites, thanks to the well-coordinated work of all branches of power and the clergy. All this is due to the unified concept of spiritual and moral education, in which every citizen of the republic takes part directly. The close and effective interaction of the clergy and various branches of power in the Chechen Republic, and to this day, gives its positive results in the formation of a civil society responsible for its destiny. Much attention is paid to the formation of spiritual and moral values, special attention is given to the younger generation of Chechen Republic, for the preservation of a given pace for the future. Great emphasis is placed on the literacy and education of the population. Since it is precisely uneducated people who most often succumb to provocations from extremism and radicalism. To date, the Chechen people, who have missed military conflicts through their own destiny on the basis of religion and nationality, are perfectly adapted and set up to prevent past mistakes and preserve peace in the republic. The concept of spiritual and moral upbringing and development of the Chechen Republic is a kind of yardstick combining true and unshakable values in which the Chechen code of honor "nokhchalla" is emphasized. The word "nokhchalla" is not translated into any other language, but every Chechen knows perfectly what it means. This is a kind of a set of rules, unwritten anywhere, concerning ethics and morality that has been guiding true Chechens from early times.

Key words: Chechen Republic, modernity, Islam, patriotism, Koran, traditionalism, spirituality, morality, extremism, radicalism, value, history, religion, power, humanity, honor, conscience, mentality, customs, responsibility.

\section{[P.X. Даудов Формирование духовно-нравственных ценностей в современной Чечне]}

В современной Чеченской Республике сформулирована особая концепция, включающая в себя духовно-нравственное воспитание подрастающего поколения. Эта концепция способствует развитию таких основополагающих ценностей как патриотизм, религиозность и традиционализм. Пройдя немало испытаний и трудностей на протяжении всей истории, чеченский народ пришел к мирному и процветающему образу существования. Конечно, во многом это благодаря успешной политике таких государственных деятелей как Президент РФ В.В. Путин и Ахмат-Хаджи Кадыров, дело которого по сей день продолжает его сын, Глава Чеченской Республики Рамзан Ахматович Кадыров. Для формирования исконно истинных ценностей в республике, задействованы практически все представители власти, духовенство и сам народ. Наличие в мире таких направлений как исламский модернизм и традиционализм, тоже повлияло на формирование духовно-нравственных ценностей чеченского общества. Из многих источников известно, что представители традиционализма выступают за сохранение тех противоположностей, благодаря слаженной работе всех ветвей ценностей, которые были еще во времена Пророка Мухаммада (нач. VII века). Иначе считают представители модернизма, которые полагают, что нужно приспособить традиционные ценности в современном мире. С этой проблемой власти и духовенства современная Чеченская Республика блестяще справляется. Все это благодаря единой концеп- 
ции духовно-нравственного воспитания, в которой каждый житель республики непосредственно принимает участие. Тесное и эффективное взаимодействие духовенства и различных отраслей власти Чеченской Республики, по сей день дает свои положительные результаты в формировании ответственного за свою судьбу гражданского общества. Колоссальное внимание в формировании духовно-нравственных ценностей уделяется подрастающему поколению Чечни, для сохранности заданного темпа на будущее. Большой акцент делается на грамотности и образованности населения. Так как именно необразованные люди, чаще всего поддаются на провокации со стороны экстремизма и радикализма. На сегодняшний день чеченский народ, пропустивший через собственную судьбу военные конфликты на почве религиозности и национальности, прекрасно адаптирован и настроен на недопущение былых ошибок и за сохранность мира в республике. Концепция духовно-нравственного воспитания и развития Чеченской Республики, является своеобразным мерилом, сочетающим в себе истинные и непоколебимые ценности, в которых подчеркивается чеченский кодекс чести «нохчалла». Слово «нохчалла» никак не переводится на другой язык, но каждый чеченец прекрасно знает, что оно обозначает. Это своеобразный свод неписаных нигде правил, касающихся нравственности, морали и этики, которыми руководствуются истинные чеченцы испокон веков.

Ключевые слова: Чечня, современность, ислам, патриотизм, Коран, традиционализм, духовность, нравственность, экстремизм, радикализм, ценность, история, религия, власть, гуманность, честь, совесть, менталитет, обычаи, ответственность.

Ramzan Kh. Daudov - senior lecturer. Chechen state university. Grozny, Russian Federation.

Даудов Рамзан Хожаевич - старший преподаватель. Чеченский государственный университет. е. Грозный, Россия.

Nowadays many countries of the West and the Middle East have evinced great interest in the Chechen Republic. To a large extent this interest is directed to how the republic was able to be rehabilitated from the looming threat of the disintegration of spiritual and traditional customs in such a short period of time. The information and psychological war imposed from the outside was completely eliminated by the successful policy of the President of the Russian Federation V.V. Putin and supported by all the Chechen people, A.A. Kadyrov. In due time Ahmat-Haji Kadyrov emphasized the preservation and popularization of the traditional, spiritual and moral values of Chechen society. To this day the way of Akhmad-Khadzhi Kadyrov is being continued by his son, the head of the Chechen Republic, the Hero of Russian Federation Ramzan Akhmatovich Kadyrov. The greatest attention in the formation of spiritual and moral values is given to the younger generation of the Chechen Republic. This is especially important to preserve and strengthen peace, customs, traditional and religious values.

In modern and developing Chechen Republic all state and municipal authorities, as well as the civil society itself, are doing tremendous work to form such spiritual and moral values as justice, honor and conscience. Spiritual and moral values in the republic derive from three components: citizenship (or patriotism), religiosity and tradition (customs, Chechen - adats). In its turn it is obvious that the specifics of the listed values require a wellcoordinated interaction between all ministries, departments, organizations and, of course, the society of the republic. For the coordination and interaction of all members of society a unified concept of spiritual and moral development has been developed in Chechen Republic. The main goal of this concept is to ensure the formation of values that reflect the very essence of the Chechen mentality. That is why a single concept of spiritual and moral development ensures the formation of such values as patriotism, humanity, honor, will and responsibility and develops a love for culture and traditions. From many historical sources it is obvious that such values were inherent in the Chechens for centuries.

At first glance it seems problematic that all strata of Chechen Republic's population, both government officials and representatives of religious institutions, are involved in the 
realization of spiritual and moral values. It seems to many that there are contradictions between these directions. That the religion of Islam, the main sources of value of which are the Qur'an and the Sunnah of the Prophet Muhammad, the Constitution of the Russian Federation and traditionalism (adats) do not have common points of contact. In many ways this is due to the willful and superficial interpretation of these sources. The so-called "enemies" of peace and stability on the territory of Russia in every possible way try to use the ignorance of many citizens citing individual suras from the Koran, then certain laws of the Russian Federation, the historically established adats (customs) of Chechens. But it is not difficult for an educated and literate person to distinguish true values from false ones. Focusing on religious authorities, on the example of the life and deeds of the Prophet Muhammad who said that the desire for knowledge is the duty of every Muslim (hadith Al-Tirmidhi), it is difficult to give up education. Only an educated person can be on the path of comprehending the truth.

In the educational system of the Chechen Republic the emphasis is on the formation of an intellectual, spiritual and free personality. One of the leading priorities of the republic's social policy is the principle of availability of education. In educational institutions spiritual and religious values are popularized because during the formation of personality a person spends most of time in educational institutions. In higher educational institutions they make time breaks to pray. Almost in all types of educational institutions, ideological and educational work is carried out, which forms such values as patriotism, morality and traditionalism. Cultivation of patriotism in a personality forms a feeling of love, respect and pride towards their homeland. Moral education develops such moral qualities as diligence and respect in the personality. All this helps one to master universal values and also develops interpersonal communication skills. The assimilation of morality in Chechen Republic occurs through respect for the rights and freedoms of another person, his value and uniqueness. For the best acquaintance with the traditions and culture of Chechen Republic national and international education is actively conducted.

Such qualities of Chechens as hospitality and respect for elders, solidarity and respect for women are historically known. Because of this there are no homes for the elderly and orphanages on the territory of the Chechen Republic. That speaks about responsibility. Especially bright such qualities as tolerance, mutual assistance and cordiality are manifested. If earlier spiritual and moral values were based only on the strength of the spirit of the Chechen people, today, the power of knowledge is also encouraged. Thanks to this the Chechens learned to solve many conflicts without resorting to force. All these are the fruits of international education, which takes into account the interests of other nations, tolerance for another position and the ability to conduct a dialogue. The popularization of spiritual, traditional, cultural and moral values in Chechen Republic is realized through science, sports, literature, music, painting and theatrical art. At the heart of the upbringing of the younger generation are not only religious figures, but also the ideals of Russian and world history. Knowledge of history warns against repetition of past mistakes.

A big role in the concept of spiritual and moral values is assigned to the formation of responsible behavior in society. As is known, according to Chechen traditions, parents are responsible for their children and their actions regardless of their age. The Chechen Republic, a relatively small subject of the Russian Federation, the number of Chechens according to the latest official data of the Federal State Statistics Service for 2018 is about 1.5 million people. Even such a large number of Chechens are not an obstacle to the fact that everyone through someone knows each other. Because of an unworthy act, crime or misdemeanor, not only the person who committed the act, but also all of his kind suffers. In order to protect their name, honor and dignity, in almost all families, parents control the behavior of their children. But there is always freedom of choice. Known many cases, when the guilty person 
refuses relatives, which motivates a person to commit good deeds and abstain from antisocial behavior.

Historically, Chechens are known for their bravery, courage and valour. All these qualities are perfectly applicable for the formation of such a value as patriotism and the development of healthy lifestyle and self-discipline skills only contribute to this. Therefore much attention is paid to sports which forms a healthy spirit in a healthy body, as well as love for the Motherland and pride for one's country.

At present various information is freely available on the territory of the Chechen $\mathrm{Re}-$ public. In the conditions of freedom of speech there is frequent propagation of distorted information aimed at destroying the public and undermining the spiritual and moral foundations of the Chechens. In such conditions a great responsibility lies with the Chechen media on information and educational work. The main task of the media of the Chechen Republic is to resist the ideology alien to Chechens.

In the formation of the spiritual and moral values of the Chechen Republic one of the most important social institutions such as family has not been left without attention. When a person is just beginning the path to his development a huge role in the formation of the values of the child is played by the family. It is the family that teaches the child to take on social roles that are necessary for him to adapt in society. Important standards of conduct, the foundations of morality and spirituality, individual qualities and inner peace are formed in the family. In its turn the family contributes to the formation of the individual and to his self-affirmation and also stimulates social and creative activity. In Chechen families parents not only direct and educate their children but also serve as an example. Spiritual and moral unity of the family is the fundamental principle of the successful formation of the necessary values in children. It is difficult to imagine the process of formation of spiritual and moral values of children of Chechen families outside of culture and traditions. Parents often take their children to various cultural and traditional events where they take interest.

Spiritual and moral education of children is the basis of every act of man, it forms a personality and defines a system of values. The very formation of spirituality begins with the interaction of the adult and the child, their deep communication where the emotional sphere of the pupil develops and the ability to comprehend his "I". With the development of spirituality in children in Chechen families first of all parents teach them justice, honor and goodness. Children receive information on important values from folk tales, songs, games and conversations. The effectiveness of this process, as noted earlier, is determined by the nature of the interaction of children and adults and the value system. To familiarize with spiritual values, children are told about the deeds of the holy sheikhs, dignitaries (teachers) and national heroes. On the basis of such value as respect, moral and spiritual health of a person is brought up. In the Chechen Republic everything is done to ensure that the child receives a comprehensive view of the environment in terms of religion, science, morality and art. The most important thing for a child is to learn such eternal human values as charity, truthfulness and compassion.

The formation of values in the modern Chechen Republic is especially influenced by culture. The cultural indicator is one of the most important indicators of the life of society and a sign of its civilization. In his time the First President of the Chechen Republic, Hero of Russian Federation, Akhmat-Khadji Kadyrov said that without culture there is no nation. Without reliance on culture it is hardly possible to raise a patriotic citizen, a creative and spiritual personality. The high level of culture in the Chechen Republic speaks about the formation of an enabling environment in the society. To develop and preserve the culture of the peoples of Chechen Republic government bodies, local government and the society itself invests huge resources and forces. It supports the historical and cultural heritage of the people; takes measures to preserve the scientific potential of educational institutions; 
develops cultural ties with other regions of the Russian Federation; takes measures to develop Chechen cinematography and actively develops theaters raising the level of their creative activity.

In Chechen Republic the activities of outstanding workers of classical art and culture of the Chechen Republic are popularized: Mahmud Esambayev, Shita Edilsultanov, Adnan Shahbulatov, Iles Tataev, Umar Dimaev, Maryam Aidamirova, Valid Dagayev, Topa Elimbaev and others. The activities of museums in Chechen Republic are focused on studying and understanding the history of the Republic and the culture of the people. In the new conditions for the development of Chechen society the museums of the Republic are the centers of active research, educational, cultural and explanatory activities. In the exhibition activity, the museums of Chechen Republic use the works of classics of painting, propagandizing such universal values as respect, kindness, patriotism, love and faith. In order to form aesthetic values, paintings of reproductions of Chechen artists are exhibited: Petra Zakharov, Shamil Shamurzayev, Amanda Asuhanov, Vakha Umarsultanov, Dadan Idrisov, Kharon Isayev, Said-Khuseyn Bitsiraev, Sultan Yushayev, Sultan Abayev, Khamzat Dadayev, Abu Pashayev and others. Many libraries of the Chechen Republic will popularize the literature of the Chechen classics: Said Baduev, Shima Okuev, Abdulla Khamidov, Khalid Oshayev, Magomed Mamakayev, Ahmed Suleymanov, Sheikhi Arsanukayev, Abuzar Aydamirov, and others by organizing exhibitions, creative evenings and other cultural events.

For all the time of its historical development Chechen Republic has always adhered to spiritual and moral values. These values have always been the consolidating force of the entire Chechen people. Undoubtedly it was easier for Chechens to accept Islam, since many of the dogmas of Islam are radically combined with the traditions of Chechens. And today traditional Islam plays an important role in the formation of spiritual and moral values. It is traditional Islam that is an obstacle and the main force that protects Chechen Republic and its people from extremist ideology. Religious culture and religious and ethical values that have developed in the Chechen Republic have a positive potential for solving many contemporary problems in the world. In the course of historical development traditional Islam in Chechen Republic is actually a powerful social and cultural factor where religion interacts with such components of culture as morality, art, science and enlightenment. As the sheikhs and uzhaz (teachers) of Chechen Republic at one time spread the most important values of Islam as an example of their own actions, so the modern generation should try to impart these values to the younger generation.

In modern Chechen Republic there are followers of all three world religions: Christianity, Islam and Judaism. The Constitution of Chechen Republic proclaims freedom of conscience. The state does not interfere in the affairs of religious organizations and religious organizations do not fulfill state functions. The state education system in the Chechen $\operatorname{Re}-$ public is secular. Proceeding from the Universal Declaration of Human Rights, where freedom of thought, conscience and religious beliefs are proclaimed, the secular nature of the state does not imply the complete isolation of religion from public life.

Religious values in Chechen Republic unite people. Joint prayer, visits to holy places (ziyarat) and many other religious and traditional events rally the people. And this is of no small importance for the preservation of peace and stability on the territory of the republic. Therefore, the clergy are used in the prevention of antisocial behavior, extremism and terrorism. In order to preserve traditional values and customs in the Chechen Republic, the potential of the media is used, ethno-cultural activities are conducted, and public authorities are assisted in research and scientific activities to study the traditions and customs of the Chechen Republic. The ongoing reassessment of spiritual and moral values in the modern Russian society has long-term bases and deep roots. A new system of spiritual and moral values will be affirmed as they become a tradition, and the old traditions will be transformed and adapted to new conditions. Spiritual and moral values are practically inalienable from 
the real conditions of our reality and are also prone to transformation. And in today's conditions it is important to help the younger generation of the republic in the perception of these values, to develop in its mind immunity and educate young people in the best traditions of the people.

\section{Лumepamypa}

1. Гусейнов А.А. Великие моралисты. М., 1995.

2. Межидов Д.Д. Чеченцы: обычаи, традиции, нравы. Грозный, 1992.

3. Саракаева A.X. Процесс фрормирования личности в чеченской народной педагогике // Актуальные вопросы современной педагогики: материалы Международной научной конференции (г. Уфра, июнь 2011 г.). Уфра, 2011. [Электронный ресурс] https://moluch.ru/conf/ped/archive/18/749/ (дата обращения: 21.06.2018).

4. Солдатенков А.Д. Патриотизм - основа духовно-нравственного воспитания. М., 1998.

5. Сухомлинский В.А. Видение гражданина. М., 1971.

6. Хасиев С.-М. Чеченцев древняя земля. Грозный, 1994.

7. Хубиева 3.А. Место и роль духовно-нравственных ценностей в социокультурном пространстве Северного Кавказа // Сборник научных трудов СевКавГТУ. Серия «Гуманитарные науки». №1. Ставрополь, 2005.

8. Хубиева 3.А. Возрастание роли духовно-нравственных ценностей в современном российском социуме // Современные социально-философфские и психолого-педагогические проблемы: Сб. научных трудов. Вып. XVIII. Ставрополь, 2005.

9. Хубиева 3.А. Природа и специфика духовно-нравственных ценностей // Материалы IX региональной научно-технической конференции «Вузовская наука по Северо-Кавказскому региону». Общественные науки. Ставрополь, 2005.

10. Чеснов Я.В. Женщина и этика жизни в менталитете чеченцев // ЭО. 1994. №5.

\section{References}

1. Guseynov A.A. Great moralists. M., 1995.

2. Mezhidov D.D. Chechens: customs, traditions, customs. Grozny, 1992.

3. Sarakaeva A.Kh. The process of personality formation in the Chechen folk pedagogy // Actual problems of modern pedagogy: materials of the International scientific conference (Ufa, June 2011). Ufa, 2011. [Electronic resource] https://moluch.ru/conf/ped/archive/18/749/ (reference date: June 21, 2013).

4. Soldatenkov A.D. Patriotism is the basis of spiritual and moral education.Moscow: MGOPU, 1998.

5. Suhomlinsky V.A. Vision of a citizen. M., 1971.

6. Khasiev S.-M. The Chechens are an ancient land. Grozny, 1994.

7. Khubieva Z.A. The place and role of spiritual and moral values in the socio-cultural space of the North Caucasus // Collection of scientific works. Series "Humanities". №1. Stavropol, 2005.

8. Khubieva Z.A. Increase in the role of spiritual and moral values in the modern Russian society // Modern socio-philosophical and psychological-pedagogical problems: Collection of scientific works. No XVIII. Stavropol, 2005.

9. Khubieva Z.A. Nature and Specificity of Spiritual and Moral Values // Materials of the IX Regional Scientific and Technical Conference "University Science in the North Caucasus Region". Social Sciences. Stavropol, 2005.

10. Chesnov Ya.V. Woman and the ethics of life in the mentality of the Chechens // EO. 1994. №5. 